\title{
Kuivamädätysbiokaasureaktorin toiminnan käynnistys
}

\author{
Elina Virkkunen ${ }^{1)}$, Mari Jaakkola ${ }^{2)}$ ja Elina Korhonen ${ }^{3)}$ \\ ${ }^{1)}$ MTT Sotkamo, Kipinäntie 16, 88600 Sotkamo, elina.virkkunen@mtt.fi \\ ${ }^{2)}$ Biotekniikan laboratorio, Kajaanin yliopistokeskus, Oulun yliopisto, Salmelantie 43, 88600 Sotka- \\ mo,mari.jaakkola@oulu.fi. \\ 3) Jyväskylän yliopisto, Bio- ja ympäristötieteiden laitos, Survontie 9, 40014 Jyväskylän yliopisto, \\ elina.m.korhonen@jyu.fi.
}

\section{Tiivistelmä}

Biokaasu on kaasuseos, jota syntyy mikrobien hajottaessa orgaanista ainetta hapettomissa olosuhteissa. Biokaasu koostuu metaanista (noin 55 \%) ja hiilidioksidista sekä pienistä määristä muita kaasuja. Metaani on puhtaasti palavaa uusiutuvaa energiaa. Sitä voidaan hyödyntää lämpönä, sähkönä tai liikenteen polttoaineena. Prosessin käsittelyjäännöksenä saadaan lisäksi lähes hajutonta lannoitetta. Suomessa maatilareaktorit käsittelevät lietelantaa sekä lisäsyötteinä muun muassa peltobiomassaa.

Tämän tutkimuksen tarkoituksena oli kokeilla kuivikelannan ja muun kiinteän materiaalin soveltuvuutta biokaasuntuotantoon. Kokeet tehtiin MTT Sotkamon puolijatkuvatoimisella ja täyssekoitteisella kuivamädätyslaitteistolla. Reaktorin tilavuus $4,5 \mathrm{~m}^{3}$ ja nestetilavuus noin $3 \mathrm{~m}^{3}$.

Reaktorin syötteinä käytettiin turpeella sekä oljella ja/tai ruokohelvellä kuivitettua lantaa ja hygienisoitua kalanperkuujätettä. Reaktorin lämpötila oli kokeiden ajan noin $35{ }^{\circ} \mathrm{C}$. Tutkimus käynnistettiin ilman ymppiä kuuden viikon panoskokeella, jossa oli syötteenä kuivalanta. Tämän jälkeen reaktoria syötettiin päivittäin 3 - 4 kuukautta kestävissä koejaksoissa. Syötteinä oli ensimmäisessä jaksossa kuivalanta (1 kg VS/m $\left.{ }^{3} \mathrm{~d}\right)$. Samoin toisessa jaksossa syötettiin kuivalantaa, mutta kuormitus kaksinkertaistettiin $\left(2 \mathrm{~kg} \mathrm{VS} / \mathrm{m}^{3} \mathrm{~d}\right)$. Viimeisessä jaksossa syötteenä oli kuivalannan ja hygienisoidun lohenperkuujätteen seos, jossa kolmannes orgaanisesta kuiva-aineesta oli peräisin kalajätteestä (kokonaissyöttö $\left.1,8 \mathrm{~kg} \mathrm{VS} / \mathrm{m}^{3} \mathrm{~d}\right)$.

Metaanintuotto oli selvästi paras kalajätettä sisältäneellä syöteseoksella (250 m³/t VS) ja alhaisin pienellä kuivalantasyötöllä (127 mt/ VS). Tuorepainoa kohti metaanintuotot olivat $55 \mathrm{~m}^{3} / \mathrm{t} \mathrm{FM} \mathrm{ja}$ $23 \mathrm{~m}^{3} / \mathrm{t}$ FM. Alhaisella syötöllä hydraulinen viipymäaika oli huomattavan pitkä, 170 päivää. Vuoden kuluessa metaanipitoisuus nousi 55,5 \%:sta 56,9 \%:iin. Samoin käsittelyjäännöksen pH kohosi 7,31:stä 7,69:ään. Tulokset rohkaisevat jatkamaan kokeita kalanperkuujätteellä. Sen hyötykäyttö on myös kalankasvatusyrittäjien intresseissä.

Pilottilaitteisto osoittautui sekoitinta lukuun ottamatta toimivaksi ja tarkoitustaan vastaavaksi. Telakuljetin ei sekoittanut reaktorin sisältöä täydellisesti. Joitain teknisiä ratkaisuja, kuten syötteen ja rejektin siirtoa ruuvikuljettimilla voi suositella myös suuremman mittakaavan laitteistoihin.

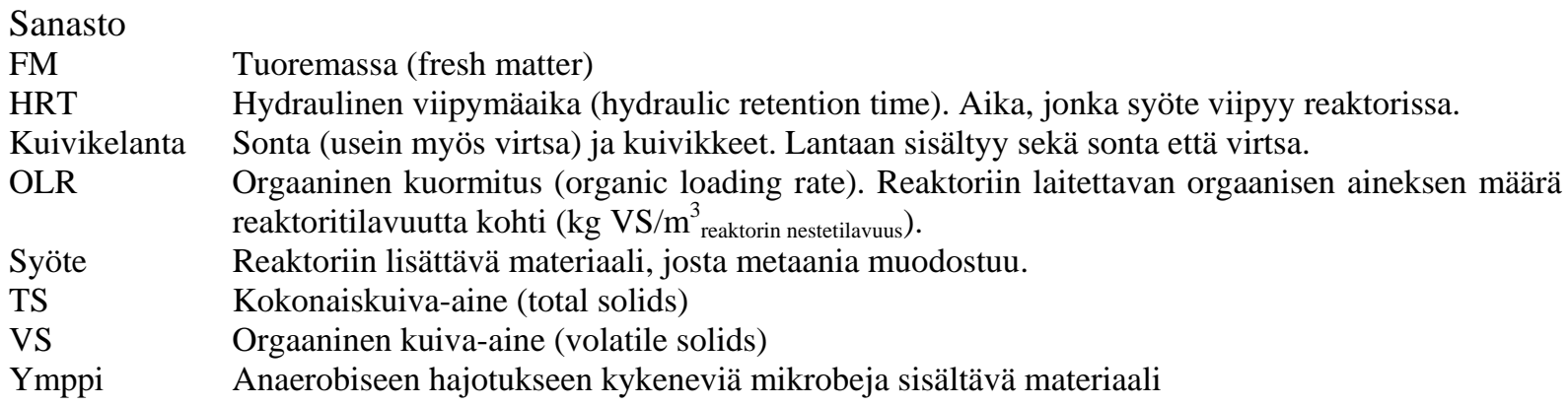

\section{Avainsanat}

biokaasu, kuivamädätys, kuivalanta, kalajäte 


\section{Johdanto}

Biokaasu on kaasuseos, jota syntyy mikrobien hajottaessa orgaanista ainetta hapettomissa olosuhteissa. Luonnossa tällaista anaerobista bakteeritoimintaa on muun muassa soissa ja eläinten suolistossa. Biokaasua voidaan tuottaa maatiloilla biokaasureaktorissa lannasta, peltobiomassasta tai tilan ulkopuolelta vastaanotettavista raaka-aineista, esimerkiksi elintarviketeollisuuden jätteistä.

Biokaasu koostuu metaanista (noin 55 \%) ja hiilidioksidista sekä pienistä määristä muita kaasuja. Metaani on puhtaasti palavaa uusiutuvaa energiaa. Se voidaan polttaa lämpökattilassa lämmöksi tai tuottaa kaasumoottorissa sähköä. Siitä voidaan valmistaa myös liikenteen polttoainetta. Biokaasureaktorin käsittelyjäännös on lähes hajutonta lannoitetta, jossa typpi ja fosfori ovat kasveille helppoliukoisessa muodossa.

Kaikki Suomessa toimivat maatilakokoluokan biokaasureaktorit käyttävät syötteenä lietemäisiä massoja. Lietteen käsittely märkäreaktorissa perustuu tunnettuun ja yleisesti käytettyyn tekniikkaan. Lietteen siirto onnistuu pumpulla ja sekoitus lapasekoittimella. Lietelannan kuiva-ainepitoisuus on $5-7 \%$. Anaerobisesti hajotettavaa materiaalia pidetään kiinteänä, mikäli sen kosteusprosentti on alle 90 (Mata-Alvarez 2000).

Lannan käsittely lietteenä on yleistynyt, mutta kuivalantajärjestelmä on edelleen yleisesti käytössä (Anon. 2009). Märkäreaktorissa käytettävät tekniikat eivät sellaisenaan sovellu kuivalannan siirtämiseen. Kuivalantojen mädätys märkänä edellyttäisi veden lisäämistä, jotta sekoittaminen ja pumppaus onnistuisivat. Tämä ei ole mielekästä, sillä se johtaa reaktorikoon suurentamiseen ja lämmitettävän massan kasvamiseen. Myös käsittelyjäännökseen tulee ylimääräistä vettä, joka on viime kädessä kuljetettava pelloille. Keski-Euroopassa toimii useammanlaisia kuivamädätyslaitoksia, mutta Suomessa ilmasto asettaa niiden toiminnalle omat haasteet.

Tämän tutkimuksen tarkoituksena oli kokeilla kuivikelannan ja muun kiinteän materiaalin soveltuvuutta biokaasuntuotantoon sellaisenaan ilman veden lisäystä. Tutkimuksessa seurattiin materiaalien biokaasunsaannon lisäksi biokaasureaktorin teknisten ratkaisujen toimivuutta.

Tutkimus sisältyy kolmivuotiseen hankkeeseen Biokaasu ja peltoenergia Kainuussa. Hanke rahoitetaan osittain Euroopan maaseudun kehittämisen maatalousrahastosta.

\section{Aineisto ja menetelmät}

Maa- ja elintarviketalouden tutkimuskeskus MTT rakensi Sotkamon toimipaikalle tutkimusmittakaavan kuivamädätyslaitteiston. Siitä suunniteltiin laboratoriomittakaavaa suurempi, jotta käytännön kokemukset ovat sovellettavissa maatilaolosuhteisiin. Laitteisto on kuitenkin selvästi tilamittakaavaa pienempi, jotta koeajoissa ei tarvita suuria massoja.

Reaktori on puolijatkuvatoiminen ja täyssekoitteinen. Sen tilavuus on $4,5 \mathrm{~m}^{3}$ ja nestetilavuus noin $3 \mathrm{~m}^{3}$ (Kuva 1). Koetoiminta reaktorilla aloitettiin elokuussa 2008.

Massa syötettiin ja poistettiin ruuvikuljettimella. Reaktorin sisältöä sekoitettiin telakuljettimella. Reaktorisäiliö on pystyasentoinen sylinteri, joka on valmistettu tavallisesta mustasta raudasta. Myös ruuvikuljettimet ovat mustaa rautaa. Telakuljetin on kumia. Kaasuputkissa on käytetty ruostumatonta terästä.

Reaktori sijaitsee puolilämpimässä tilassa, jossa ilman lämpötila pidetään nollan asteen yläpuolella. Syöttösuppilo on kylmässä tilassa. Reaktoria ja talvella myös syöttösuppiloa lämmitettiin kiertovedellä, joka myöhemmin vaihdettiin pakkasnesteeseen.

Kaasu johdetaan ensin ulos kondenssivesikaivoon, sitten takaisin reaktorihuoneeseen kaasun metaanipitoisuusmittarille (Simrad GD10P IR-kaasunilmaisin) ja määrämittarille (Elster Instromet BK-G4). Kaasua ei hyödynnetty, vaan se johdettiin soihtupolttimelle. Reaktorin syötteenä käytettiin lihanautatilan kuivalantaa, jota haettiin traktorin etukuormaajalla kerran viikossa. Myös virtsa oli imeytetty kuivikkeisiin. Tilalla käytettiin kuivikkeena turvetta sekä olkea ja/tai ruokohelpeä.

Kuivikelannasta määritettiin TS (kokonaiskuiva-aine)- ja VS (orgaaninen kuiva-aine)pitoisuudet sekä $\mathrm{N}$ - ja $\mathrm{NH}_{4}$-pitoisuudet Oulun yliopiston Biotekniikan laboratoriossa. Kokonaistypen määrityksessä käytettiin Kjeldahl-menetelmää (AACC 46 - 12) ja ammoniumtypen määrityksessä CE kapillaarielektroforeesia ja sovellettua Kjeldahl-menetelmää. TS-pitoisuus saadaan, kun näyte pidetään 15 - 20 h $105^{\circ} \mathrm{C}$ :ssa. VS-pitoisuuden määrittämiseksi kuivatut näytteet pidetään 2 tuntia $550{ }^{\circ} \mathrm{C}$ :ssa ja saadun tuhkan massa vähennetään kokonaiskuiva-aineen massasta.

Vuoden 2008 aikana TS- ja VS-näytteistä tehtiin kolme rinnakkaismääritystä, joista laskettiin keskiarvo. Vuoden 2009 alusta määritysten keskiarvo laskettiin kahdesta rinnakkaisnäytteestä. VS- 
pitoisuuden perusteella laskettiin kulloisenkin koejakson kuormitusta vastaava syöttömäärä ja lanta punnittiin saaveihin päiväannoksiin.

Yhdellä koejaksolla reaktoriin syötettiin lannan lisäksi lohenperkuujätettä. Se sisälsi kalanruodot, päät, sisälmykset ja fileoinnin yhteydessä ruotoon jäänyttä lihaa. Kalanperkuujätettä muodostuu kainuulaisilla kalanviljelylaitoksilla noin 140 tonnia vuodessa. Euroopan parlamentin ja neuvoston sivutuoteasetus (EY N:o 1774/2002) määrittelee sen kolmannen luokan jätteeksi. Tähän mennessä kalajätettä on syötetty turkiseläimille, käytetty petoeläinten houkuttelemiseen luontokuvauspaikoille, haudattu maahan ja viety kaatopaikalle. Kalajäte haettiin jäätyneenä teuraskaloja kasvattavalta laitokselta. Jäte sulatettiin ja hienonnettiin myllyllä $10 \mathrm{~mm}$ palakokoon. Hienonnettua massaa kuumennettiin ulkotiloissa 60 litran kippikattilassa $70{ }^{\circ} \mathrm{C}$ :ssa tunnin ajan. Jäähtynyt kalamassa punnittiin ämpäreihin (7 kg/ämpäri). Kokeessa massaa syötettiin reaktoriin 3,5 kg päivässä. Käsitellystä kalasta määritettiin samoin TS- ja VS-pitoisuudet sekä $\mathrm{N}$ - ja $\mathrm{NH}_{4}$-pitoisuudet.

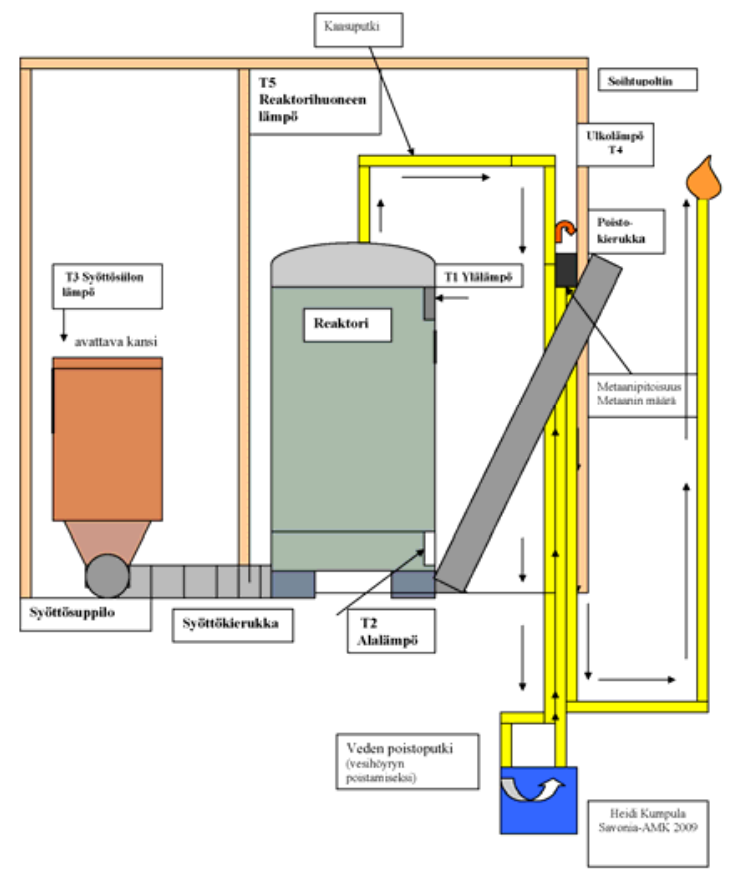

Kuva 1. Kaavakuva MTT Sotkamon puolijatkuvatoimisesta ja täyssekoitteisesta kuivamädätysreaktorista.

Reaktoritutkimus aloitettiin kuuden viikon panoskokeella. Ymppimateriaalia ei haettu missään vaiheessa, vaan prosessissa tarvittava bakteerikanta muodostui syötteenä käytetystä lannasta. Panoskokeen jälkeen reaktoria alettiin syöttää viitenä päivänä viikossa. Kuormitukset laskettiin seitsemälle päivälle, mutta viikossa syötettävä annos jaettiin viidellä. Ennen syöttöä poistettiin käsittelyjäännöstä noin 25 litraa. Se oli suunnilleen sama tilavuus kuin päivittäin lisättiin. Reaktorin sisällä olevan massan pinta pyrittiin pitämään hieman kurkistusikkunan alapuolella.

Reaktorin sisältö oli neljännessä koejaksossa noin $35^{\circ} \mathrm{C}: s s a$, mutta kolmessa ensimmäisessä kokeessa lämpötila jäi hieman alle sen. Reaktoria $\mathrm{pH}$ mitattiin alussa jokaisen poiston yhteydessä, mutta jo toisella koejaksolla siirryttiin mittaamaa $\mathrm{pH}$ kahdesti viikossa. $\mathrm{pH}$ mitattiin MTT Sotkamon laboratoriossa (Orion research SA 720 pH/ISE-mittari).

Reaktorilla on tehty neljä koejaksoa:

1) Ensimmäinen koejakso 19.08.2008 - 30.9.2008 oli panoskoe, jonka syötteenä käytettiin kuivalantaa. Panos syötettiin reaktoriin kerralla, ja sitä pidettiin siellä 43 vuorokautta. Reaktoria sekoitettiin 30 min - 1 h päivässä lukuun ottamatta ensimmäisiä päiviä.

2) Toisella koejaksolla 1.10.2008 - 16.2.2009 reaktoria syötettiin kerran päivässä. Syöte oli kuivalantaa, syöttö 1 kg VS/m³ d. Sekoitin oli käynnissä noin 1 h/d. 
3) Kolmas koejakso kesti 17.2.2009 - 30.6.2009, ja syöttö oli päivittäistä. Syöte oli kuivalantaa, syöttö $2 \mathrm{~kg} \mathrm{VS} / \mathrm{m}^{3}$ d. Sekoitin tukkeutui ja katkesi jakson aikana. Reaktori jouduttiin tyhjentämään ja sen jälkeen täyttämään uudelleen.

4) Neljäs koejakso toteutettiin 1.7.2009 - 30.10.2009 edelleen päivittäisellä syötöllä. Syöttömäärä oli $1,8 \mathrm{~kg} \mathrm{VS} / \mathrm{m}^{3}$ d, syöte oli kuivalantaa (2/3 koko VS:stä) ja kalanperkuujätettä (1/3 koko VS:stä), sekoitusaika noin $8 \mathrm{~h} / \mathrm{d}$.

\section{Tulokset ja tulosten tarkastelu}

Reaktori täytettiin aluksi kuivalannalla ilman ymppimateriaalia ja tehtiin panoskoe. Syöte oli niin kiinteää, ettei telakuljetin liikkunut aluksi lainkaan. Lanta sisältää monipuolisen mikrobiston, ja bakteeritoiminta lähtee helposti käyntiin sopivissa olosuhteissa ilman ymppiäkin. Kolmantena päivänä täytön jälkeen massa oli jo löystynyt bakteeritoiminnan ansiosta sen verran, että telakuljetin toimi. Sekoitin havaittiin kuitenkin teholtaan heikoksi. Se ei sekoittanut koko massaa, vaan reunoille jäi lähes sekoittumaton alue.

Viikon jälkeen kaasuntuotanto lähti jyrkkään nousuun, ja kolmen kuution massasta saatiin enimmillään 3,5 $\mathrm{m}^{3}$ biokaasua vuorokaudessa (Kuva 2). Panoksesta saatiin yhteensä $72 \mathrm{~m}^{3}$ biokaasua 43 vuorokaudessa. Metaanin määrää ei mitattu.

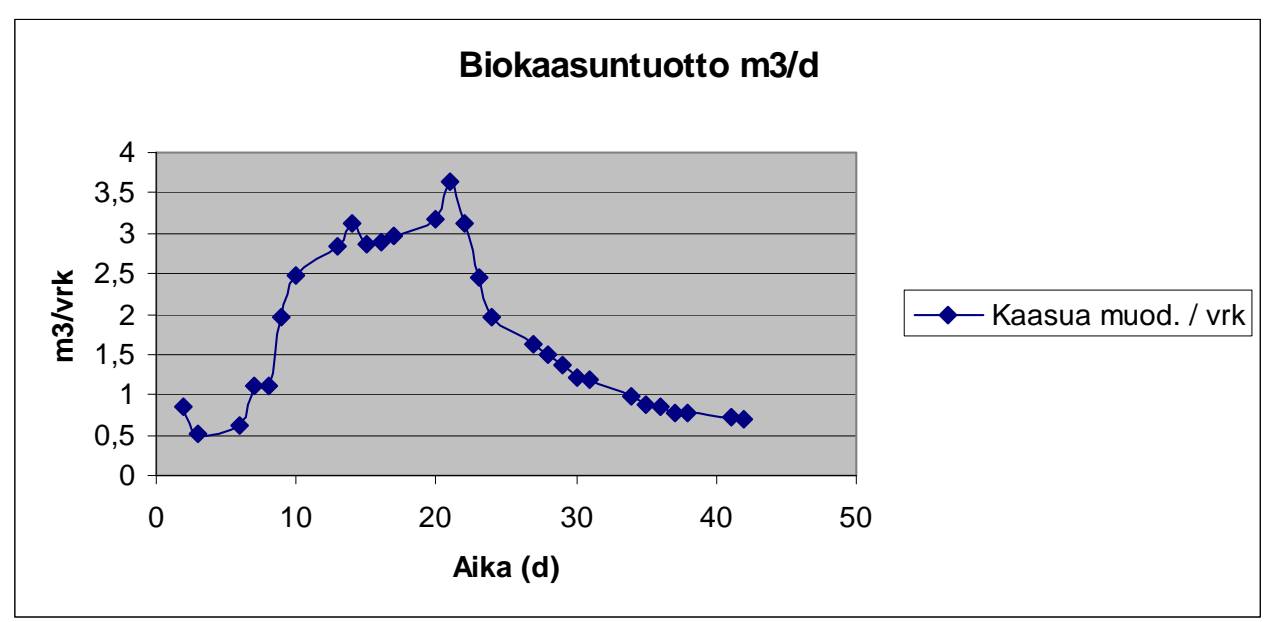

Kuva 2. Biokaasun muodostuminen panoskokeessa.

Toinen koejakso aloitettiin välittömästi panoskokeen jälkeen. Panoskokeen aikana reaktorisssa oli käynnistynyt anaerobinen mikrobitoiminta. Reaktoria alettiin syöttää ja käsittelyjäännöstä poistaa päivittäin. Orgaaninen kuormitus pidettiin matalana $\left(1 \mathrm{~kg} \mathrm{VS} / \mathrm{m}^{3} \mathrm{~d}\right)$, ja syöte hajosi prosessissa hyvin.

Kolmannella koejaksolla oli tarkoitus kaksinkertaistaa reaktorin orgaaninen kuormitus. Sekoittimena toiminut telakuljetin joutui kovalle rasitukselle, varsinkin kun syötteen joukossa oli pitkäksi jäänyttä olkikuiviketta. Sekoittimen hihna katkesi 37 päivän jälkeen. Reaktorisäiliö tyhjennettiin ja hihna sekä laakerit korjattiin. Reaktorin sisältöä otettiin talteen etukuormaajaan ja lisättiin reaktoriin, kun sitä käynnistettiin uudelleen. Uutta massaa lisättiin noin $45 \mathrm{~kg} / \mathrm{d}$, kunnes säiliön sisältö oli samalla tasolla kuin ennen katkosta. Lisäysvaiheeseen kului 9 viikkoa. Tämän jälkeen kuormitusta (2 kg VS/m $\mathrm{m}^{3}$ d) jatkettiin vielä 30 päivän ajan.

Reaktoria täytettiin vähitellen ja samalla sitä sekoitettiin noin 8 h/d, jotta reunoille ei kertyisi sekoittumatonta massaa. Tässä onnistuttiinkin, sillä sisällön pinta oli tasainen, eikä reunoiltaan koholla. Ilmeisesti sekoitin toimi kuitenkin kapasiteettinsa äärirajoilla. Tämä koejakso jäi katkonaiseksi, eikä siitä saatu luotettavaa tulosta. Tuloksissa on eritelty alkujakso (17.2.09 - 26.3.09) ja katkoksen jälkeinen loppujakso (11.5.09 - 30.6.09).

Neljännellä koejaksolla syöttö oli $1,8 \mathrm{~kg} \mathrm{VS} / \mathrm{m}^{3} \mathrm{~d}$. Syötteenä oli kuivalannan lisäksi kalanperkuujätettä. Kalaa lisättiin päivittäin kymmenesosa tuoremassasta ja kolmasosa VS:stä.

Lannan TS \%:n keskiarvo vaihteli jaksojen aikana 20,3:sta 26,4:ään ja käsittelyjäännöksen TS \%:n keskiarvo 11,3:sta 19,7:ään (Taulukko 1). Toisen koejakson käsittelyjäännös oli vellimäistä ja lähes hajutonta ja siinä VS \%:n vähenemä oli suuri, 48,7 \%. 
Taulukko 1. Koejaksojen reaktorikuormitukset sekä syötteiden ja käsittelyjäännöksen TS- ja VS-pitoisuudet.

\begin{tabular}{llllllll}
\hline $\begin{array}{l}\text { koe- } \\
\text { jakso }\end{array}$ & $\begin{array}{l}\text { kuormitus } \\
\text { kg VS/m }\end{array}$ & $\begin{array}{l}\text { TS } \% \\
\text { lanta }\end{array}$ & $\begin{array}{l}\text { VS \% } \\
\text { lanta }\end{array}$ & $\begin{array}{l}\text { TS \% käsit- } \\
\text { telyjäännös }\end{array}$ & $\begin{array}{l}\text { VS \% käsit- } \\
\text { telyjäännös }\end{array}$ & $\begin{array}{l}\text { TS \% } \\
\text { kala }\end{array}$ & $\begin{array}{l}\text { VS \% } \\
\text { kala }\end{array}$ \\
\hline 2 & $0,977 \pm 0,044$ & $20,9 \pm 2,5$ & $18,7 \pm 2,3$ & $11,3 \pm 2,3$ & $9,6 \pm 2,0$ & & \\
3 alku & $1,887 \pm 0,187$ & $20,3 \pm 3,7$ & $18,3 \pm 3,7$ & $16,7 \pm 1,1$ & $14,6 \pm 1,1$ & & \\
3 loppu & $2,069 \pm 0,447$ & $26,4 \pm 3,9$ & $23,5 \pm 3,5$ & $17,2 \pm 3,0$ & $14,8 \pm 2,7$ & & \\
4 & $1,802 \pm 0,097$ & $21,1 \pm 2,0$ & $18,9 \pm 1,9$ & $19,2 \pm 0,4$ & $16,3 \pm 0,3$ & $54,7 \pm 3,1$ & $51,7 \pm 2,5$ \\
\hline
\end{tabular}

Toisessa jaksossa syötteen reaktorissa viipymä aika oli alhaisen syötön vuoksi pitkä, keskimäärin 170 vuorokautta. Viipymä lasketaan jakamalla reaktorin tilavuus sinne päivittäin syötetyn massan tilavuudella (Taulukko 2). Kalan lisäys nosti huomattavasti biokaasun ja metaanin tuotantoa. Alhaisella lantasyötöllä metaanintuotto oli keskimäärin $127 \mathrm{~m}^{3}$ VS-tonnia kohti, kun vastaava arvo kalajätteen lisäyksen jälkeen oli keskimäärin 250. Tuoremassaa kohti laskettuna metaaninsaanto oli alhaisella syötöllä keskimäärin $23 \mathrm{~m}^{3} / \mathrm{t}$ FM ja kalajätettä syötettäessä keskimäärin $55 \mathrm{~m}^{3} / \mathrm{t} \mathrm{FM}$ (Taulukko 2, Kuva 3). Biokaasun metaani-\% kohosi hieman koejaksojen edetessä. Vuoden kuluessa metaanipitoisuus nousi 55,5 \%:sta 56,9 \%:iin. Samoin käsittelyjäännöksen pH kohosi 7,31:stä 7,69:ään (Taulukko 2).

Taulukko 2. Koejaksojen metaanisaannot, metaaniprosentit, viipymät ja käsittelyjäännöksen pH:t.

\begin{tabular}{llllll}
\hline koejakso & $\begin{array}{l}\mathrm{m}^{3} \text { metaania/ } \\
\text { t VS, viikko- } \\
\text { keskiarvo }\end{array}$ & $\begin{array}{l}\mathrm{m}^{3} \text { metaania/ } \\
\mathrm{t} \text { FM, viikko- } \\
\text { keskiarvo }\end{array}$ & metaani \% & $\begin{array}{l}\text { viipymä d, } \\
\text { viikko- } \\
\text { keskiarvo }\end{array}$ & $\begin{array}{l}\text { käsittely- } \\
\text { jäännöksen } \mathrm{pH}\end{array}$ \\
\hline 2 & $127 \pm 23$ & $23,08 \pm 4,76$ & $55,5 \pm 1,4$ & $170 \pm 16$ & $7,31 \pm 0,09$ \\
3 alku & $93 \pm 31$ & $15,24 \pm 3,28$ & $55,2 \pm 1,7$ & $87 \pm 15$ & $7,39 \pm 0,07$ \\
3 loppu & $157 \pm 59$ & $34,94 \pm 10,43$ & $53,8 \pm 1,5$ & $106 \pm 29$ & $7,53 \pm 0,16$ \\
4 & $250 \pm 32$ & $55,06 \pm 6,72$ & $56,9 \pm 2,3$ & $132 \pm 11$ & $7,69 \pm 0,12$ \\
\hline
\end{tabular}

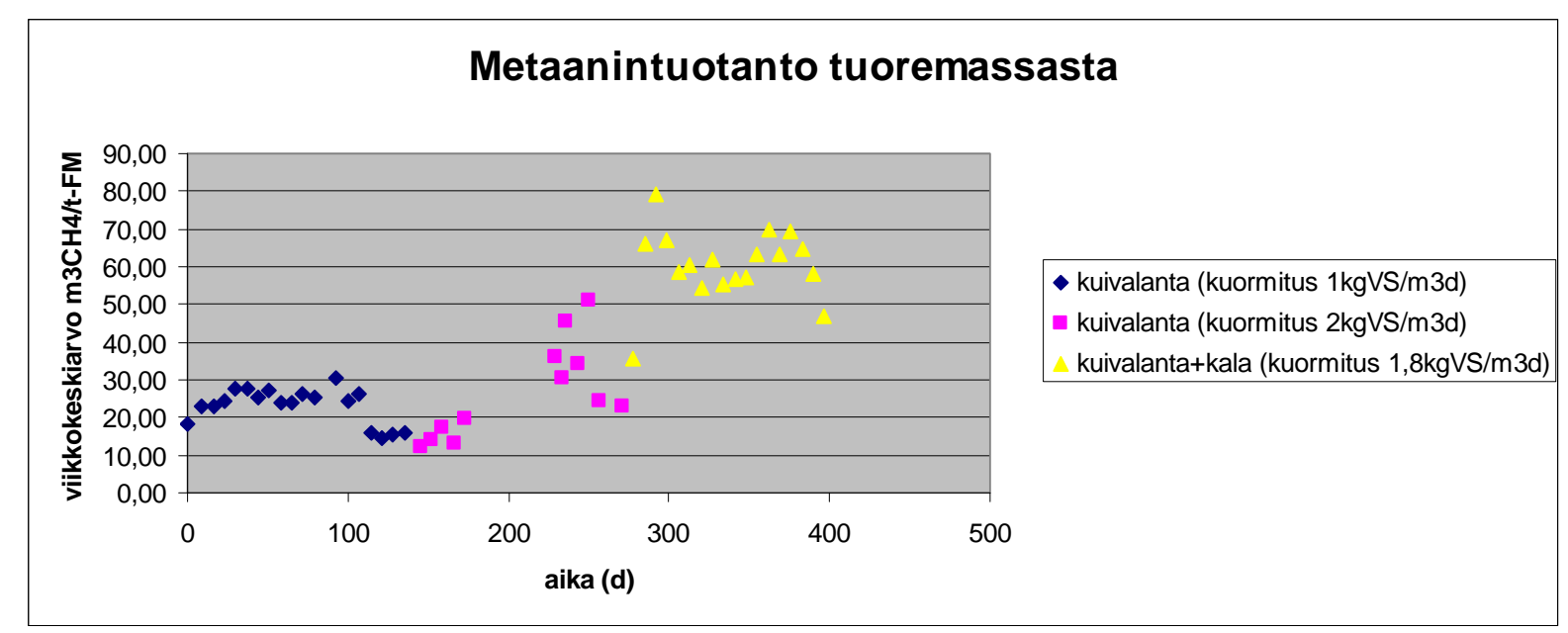

Kuva 3. Metaanintuotanto tuoreesta massasta eri kuormituksilla.

Ammonium suhteessa kokonaistyppeen oli selvästi suurempi käsittelyjäännöksessä kuin syötteenä käytetyssä lannassa (Kuva 4). Tulos oli odotettu, sillä osa typestä muuttuu biokaasuprosessissa ammoniumtypeksi. Kuva 4 ei vastaa täysin todellisuutta, sillä käsittelyjäännös sisältää kalajätteen typen, mutta syötteen typpi on kuvaajassa mukana vain lannan osalta. 


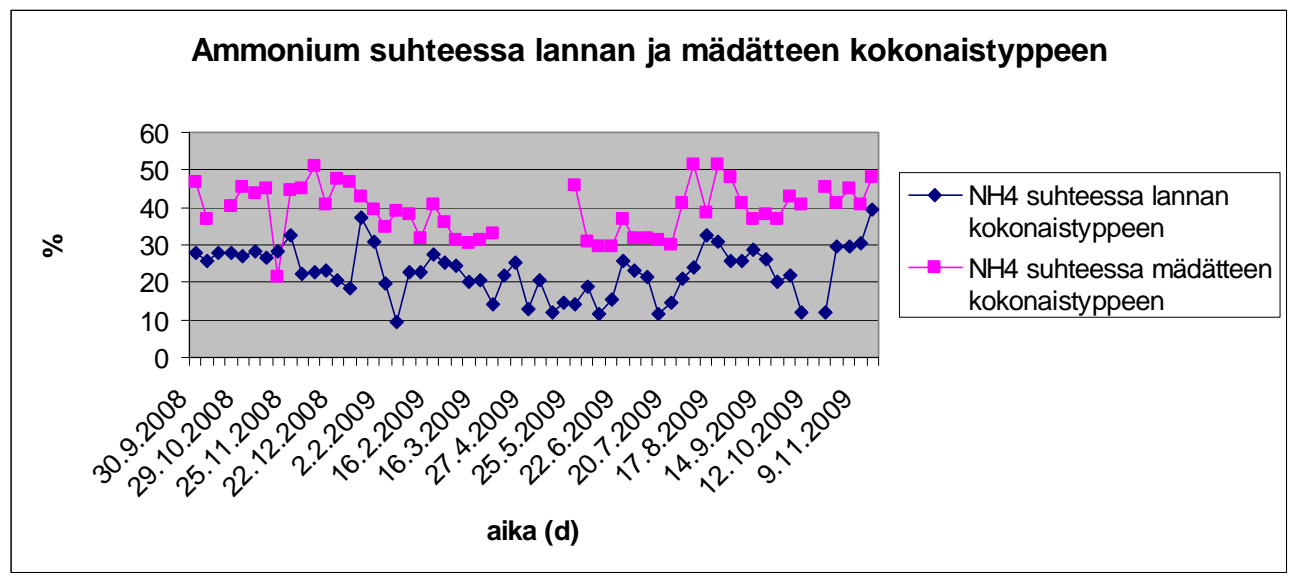

Kuva 4. Ammonium suhteessa typen kokonaismäärään lannassa ja mädätteessä. Syötteeseen 1.7.09 alkaen sisältyneen kalajätteen typpeä ei ole tässä huomioitu.

\section{Johtopäätökset}

Panoskoe osoitti, että mikrobitoiminta käynnistyi muutamassa päivässä itsekseen lannan sisältämän monipuolisen mikrobiston ansiosta. Vaikka ympin lisääminen oletettavasti nopeuttaisi mikrobitoiminnan alkamista, se ei ole välttämätöntä, jos syötteenä on lanta.

Metaanintuotto oli koejaksoilla hyvä tai keskimääräinen; 0,093-0,250 $\mathrm{m}^{3} \mathrm{CH}_{4} / \mathrm{kg}$ VS. Mollerin ym. (2004) kokeissa metaania saatiin naudan sonnasta $0,10-0,16 \mathrm{~m}^{3} \mathrm{CH}_{4} / \mathrm{kg}$ VS. Tulokset eivät ole täysin vertailukelpoisia, sillä Mollerin ym. tutkimuksissa ei ollut mukana kuivikemateriaalia.

Kun reaktoria syötettiin pienellä päivittäisellä määrällä toisessa kokeessa, viipymä muodostui kovin pitkäksi 170. Vähäinen syöttömäärä vaatisi tarpeettoman suuren reaktorin. Pienen syötön hyvänä puolena oli syötteen perusteellinen hajoaminen. Ilmeisesti lannan lähes koko orgaaninen aines ehti hajota, sillä sen vähenemä oli 48,7 \%. Suuri osa kuivikelannasta on hitaasti hajoavaa turvekuiviketta. Schäferin ym. (2006) mukaan kuivikkeiden osuus kuivikelannan VS:stä on 53 - 70 \%. Sekoittimena toimivan telakuljettimen heikko teho estää kuormituksen lisäämisen yli $2 \mathrm{~kg} \mathrm{VS} / \mathrm{m}^{3} \mathrm{~d}$ tasolle.

Kalanperkuujätteen lisääminen lisäsi lannan kaasunsaantoa huomattavasti. Kalan osuuden kasvattaminen biokaasureaktorin syötteestä onkin seuraava kokeilun kohde. On oletettavaa, että typpipitoisen syötteen, kuten kalanperkuujätteen ammoniakki alkaa jossain vaiheessa inhiboida metaanibakteerien toimintaa (Chamy, ym. 1998). Kalanperkuujäte on mielenkiintoinen materiaali myös hyvän saatavuutensa vuoksi. Se on kalankasvattajille jäte, jolle yrittäjät ovat halukkaita löytämään mielekästä käyttöä.

Laitteisto on osoittautunut sekoitinta lukuun ottamatta tarkoitustaan vastaavaksi. Koeajot ja datan keruu ovat onnistuneet tyydyttävästi tai hyvin. Syötteen lisäys kuivamädätyslaitteistoon syöttösuppilon kautta ja rejektin poisto poistoruuvilla onnistuivat ilman ongelmia. Ainoastaan syötteen TSpitoisuuden ollessa toistuvasti alle $20 \%$, ruuvi ei kuljettanut massaa eteenpäin, vaan reaktorin sisältö alkoi valua takaisin syöttösuppiloon. Tilanne korjautui lisäämällä kiinteämpää syötettä. Aivan sellaisenaan reaktorin mittakaava ei sovi suurennettavaksi, mutta joitain teknisiä ratkaisuja voidaan myös hyödyntää maatilamittakaavan reaktorissa.

\section{Kirjallisuus}

Anonyymi 2009. Greenhouse gas emissions in Finland 1990-2007. National inventory report under UNFCCC and Kyoto protocol. 8 April 2009. Suomen tilastokeskus. http://www.stat.fi/tup/khkinv/fi_nir_030409.pdf

Anonyymi 2005. EY N:o 93/2005. Komission asetus (EY) N:o 93/2005, annettu 19 päivänä tammikuuta 2005, Euroopan parlamentin ja neuvoston asetuksen (EY) N:o 1774/2002 muuttamisesta kalaperäisten eläimistä saatavien sivutuotteiden käsittelyn sekä eläimistä saatavien sivutuotteiden kuljetuksessa vaadittavien kaupallisten asiakirjojen osalta.

Chamy, R., Poirrier, P., Schiappacasse, M., Alkalay, D., Guerrero, L. 1998. Effect of ammonia content in the biodegradability of the salmon industry wastes. Bioprocess Engineering 19: 1-5. 
Mata-Alvarez, J., Macé, S. \& Llabrés, P. 2000. Review paper. Anaerobic digestion of organic solid wastes. An overview of research achievements and perspectives. Bioresource Technology 74:3-16.

Moller, H., Sommer, S. \& Ahring, B. 2004. Methane productivity of manure, straw and solid fractions of manure. Biomass and bioenergy 26: 485 - 495.

Schäfer, W., Lehto, M. \& Teye, F. 2006. Dry anaerobic digestion of organic residues on-farm - a feasibility study. Agrifood Research Reports 77. MTT Agrifood Research Finland. 